\title{
Analysis Of Landslide Materials Spreading In Bendan Dhuwur Village Gajahmungkur Subdistrict Semarang City
}

\author{
Devina Trisnawati ${ }^{1,{ }^{*}}, \mathrm{Najib}^{1}$, Istiqomah Ari Kusuma $^{1}$ and Anissa Fitratul Husna ${ }^{1}$ \\ ${ }^{1}$ Geological Engineering Department, Diponegoro University, Semarang - Indonesia
}

\begin{abstract}
Bendan Dhuwur is one of area in Semarang city, which continuously has landslide problem. This problem resulted in damage of some buildings and main road. Landslide materials/coluvial have been estimated lays on under those infrastructures and tend to move during rainy season. Therefore, it needs to understand the spread of coluvial to minimize the effect of landslide. Remote sensing method has been used to analyze multi temporal image for mapping landslide materials from different years recorded direction of creep and spread of coluvials. This method has been combined with surface and subsurface data from mapping and resistivity data. The analysis result on map which show that the coluvial material spreads on the south side, beneath the University of Tujuh Belas Agustus construction and Pawiyatan Luhur road. Its move to east leads to the Kaligarang river.
\end{abstract}

\section{Preliminary}

Landslide is one process that works in changing the face of the earth. This process can work quickly or slowly. Generally, the process of land slide has either work quickly or slowly a negative effect on society. One of the negative effect of the land slide slowly felt by the people in Bendan Dhuwur Village, Gajahmungkur Sub-district, Semarang City, especially in Pawiyatan Luhur road.

The process of land slide slowly resulted in Pawiyatan Luhur road which is the nearest access from Sampangan to Jatingaleh experiencing subsidence. Road repair periodically done by the Public Works Department does not have much impact on the road, because subsidence still occurs especially in the rainy season. According to [1] colluvial material on the slope bend causes the material always move especially in the rainy season. Based on this, the research is aimed to find out the distribution of colluvial material which is estimated to be under the Pawiyatan Luhur road. Material distribution can be interpreted by remote sensing method.

Remote sensing method makes it easier to observe the research object in quite wide locations research. In addition, the use of remote sensing for the compilation of landslide databases has been done a lot nowadays because it can load past information data up to now $[2,3,4,5]$. The use of remote sensing methods combined with surface geology and resistivity data to compare remote sensing interpretation results with actual geological conditions (ground checking). From the interpretation result of the distribution of colluvial material then directed the effort of controlling the movement of creeping during the rainy season.

\section{Study Area}

The location of research belongs to administrative area of Semarang City, Gajahmungkur sub district Bendhan Dhuwur Village (Fig.1). In general, the study area has a morphological condition that characterizes the result of structural formation [6].



Fig. 1. Research Area.

\footnotetext{
Corresponding author: tdvina812@gmail.com
} 


\section{Research Method}

\subsection{Image Processing}

Image processing is intended to interpret changes in the form of land in the location research. Imagery used in the form of Landsat 7 ETM+ image from different year (2014 and 2016) got from USGS. Image processing is done with Er Mapper 7.1 and Arc Map 10.1 software.

Information about landslide from remote sensing is closely related to morphology, especially the slopes. The interpretation of the landslide is based on the introduction of changes occurring in the landform which is associated with the slope [2]. Changes in landforms especially on slope buckling may be indicated as avalanche material.

Image processing begins with geometric correction aim to correcting recording errors, resulting in uniformity of coordinate system and scale in image. The corrected research image is subsequently cut in accordance with them. The next process is image masking to get the desired display. The Red Green Difference method is used in analyzing changes in the landform. The contrast of green and red colors from different year images is an indication of a change in the landform. Digitization is done to record the changes of existing land form so that the limitation of the spread of landslide material is obtained.

\subsection{Interpretation of Surface and Subsurface Data}

In addition to image data that has been processed, still required surface data conditions and subsurface research area. Surface data was obtained by mapping the soil / rock type. Mapping is needed to ensure the difference of landslide material results with residual soil or in situ rocks in the research area. The landslide material consists of earth and debris, where the earth has a material composition with grain size smaller than $2 \mathrm{~mm}$ as much as $80 \%$, while debris has a material composition with grain size of more than $2 \mathrm{~mm}$ as much as $20-80 \%$ [7]

The subsurface data used in this research is resistivity data. The resistivity value reflects soil / rock conditions [8] which is obtained from 6 measurement points in the research location. The measurement point is placed in the area with the expected lithology of a landslide material. Measurements were performed with a total line of $100 \mathrm{~m}$ by the Schlumberger method. Furthermore, the analysis is done with Progress 3.0 software to determine the resistivity value of soil / rock. According to[9] the resistivity value from another research presented in Table 1 .
Table 1.Parameter of resistivity value [9].

\begin{tabular}{|c|c|}
\hline Resistivity Value & $\begin{array}{c}\text { Interpretation } \\
\text { of Rock }\end{array}$ \\
\hline $101-1.000 \Omega \mathrm{m}$ & Breccia \\
\hline $51-100 \Omega \mathrm{m}$ & $\begin{array}{c}\text { Tuffaceous } \\
\text { Sandstone / } \\
\text { Tuffaceous Sand }\end{array}$ \\
\hline $20-50 \Omega \mathrm{m}$ & Tuff \\
\hline $1-50 \Omega \mathrm{m}$ & Claystone \\
\hline
\end{tabular}

\section{Results and Discussion}

\subsection{Image Interpretation}

Visual interpretation of Landsat ETM 7+ images with different years, which is 2014 and 2016 has done. The interpretation process using red green difference method, this method using two layers with different raster data sets. The green layer contains image of year 2014 and red layer contains image of year 2016, by using band 4 of each layer. The changes of the landform show on red and green colors contrast on the raster dataset (Fig. 2 ).Area without any significant changes will show yellow colors.

\subsection{Surface and Subsurface Condition}

\subsubsection{Lithology Mapping}

In general, the research area is composed of volcanic rocks [10]. Morphology of the hills with the lowest point $17 \mathrm{msl}$ and the highest $100 \mathrm{msl}$. Based on the mapping results (Fig.3) the lithology of research area consists of:

a. Alluvium deposit

It is a precipitation or deposition of river activity, so it is commonly found around the river. This deposit is encountered in a loose, light gray with a variation in the size of clay until boulder (Fig.4a).

b. Colluvial Deposition

Choluvial deposition is a precipitate of soil movement results. On the field is characterized by a light brown color - dark brown. It is a loose deposit with variations in clay grain size (Fig.4b).

c. Tuffaceous Sandstone

This type of lithology is found in almost $50 \%$ of the research area. The appearance of the field (Fig.4c) can be distinguished by the lithology of the brownish-yellow, with grain size 2 to $32 \mathrm{~mm}$. In general, lithology in a fresh state - decayed with a thickness varying between $50 \mathrm{~cm}-1$ meters.

d. Volcanic Breccia

This lithology is under the tuffaceous sandstone layer. Characterized by a light brown color, the composition of the grain-sized matrix varies from clay - sand and gravel - sized fragments. Found in massive circumstances with a slight decay (Fig 4d). 


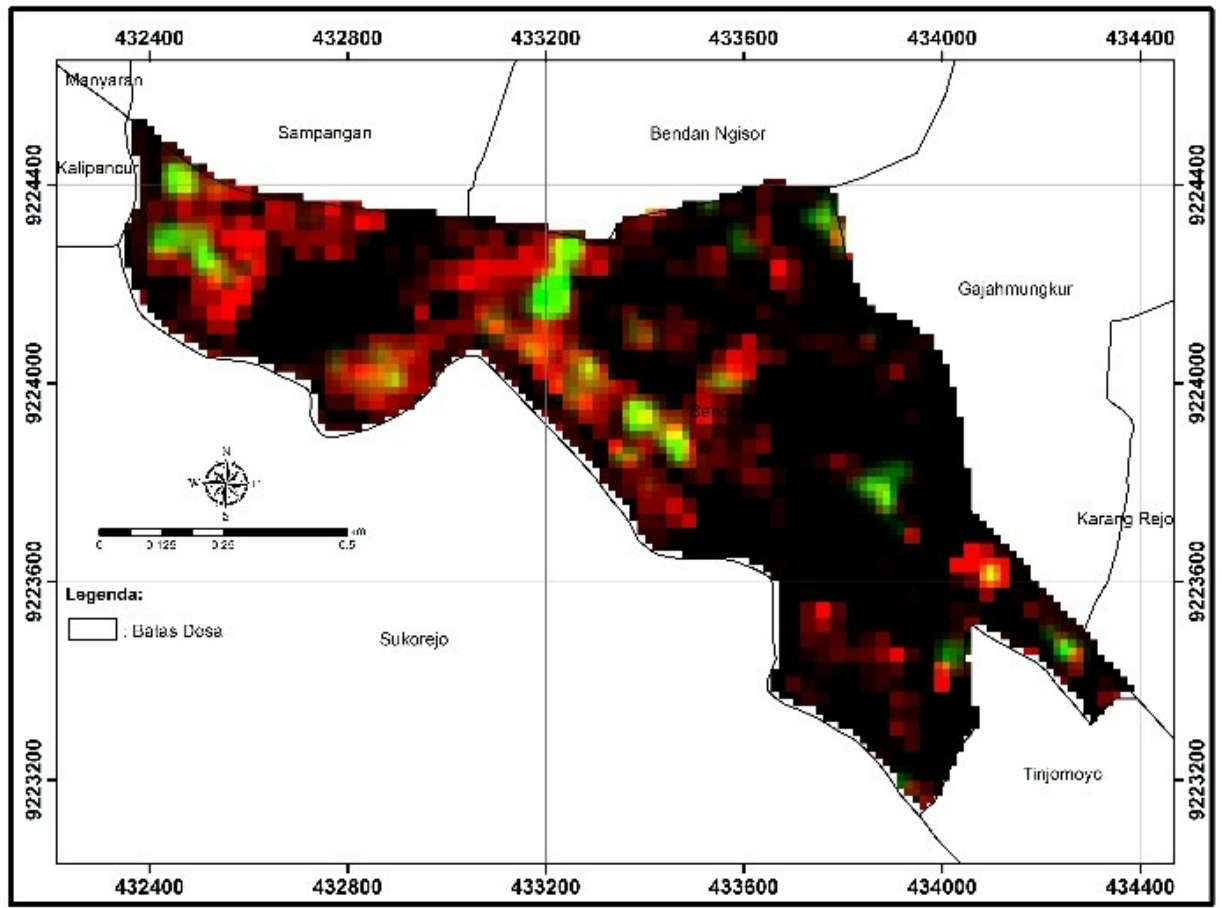

Fig. 2.Image of Red Green Difference Interpretation Result

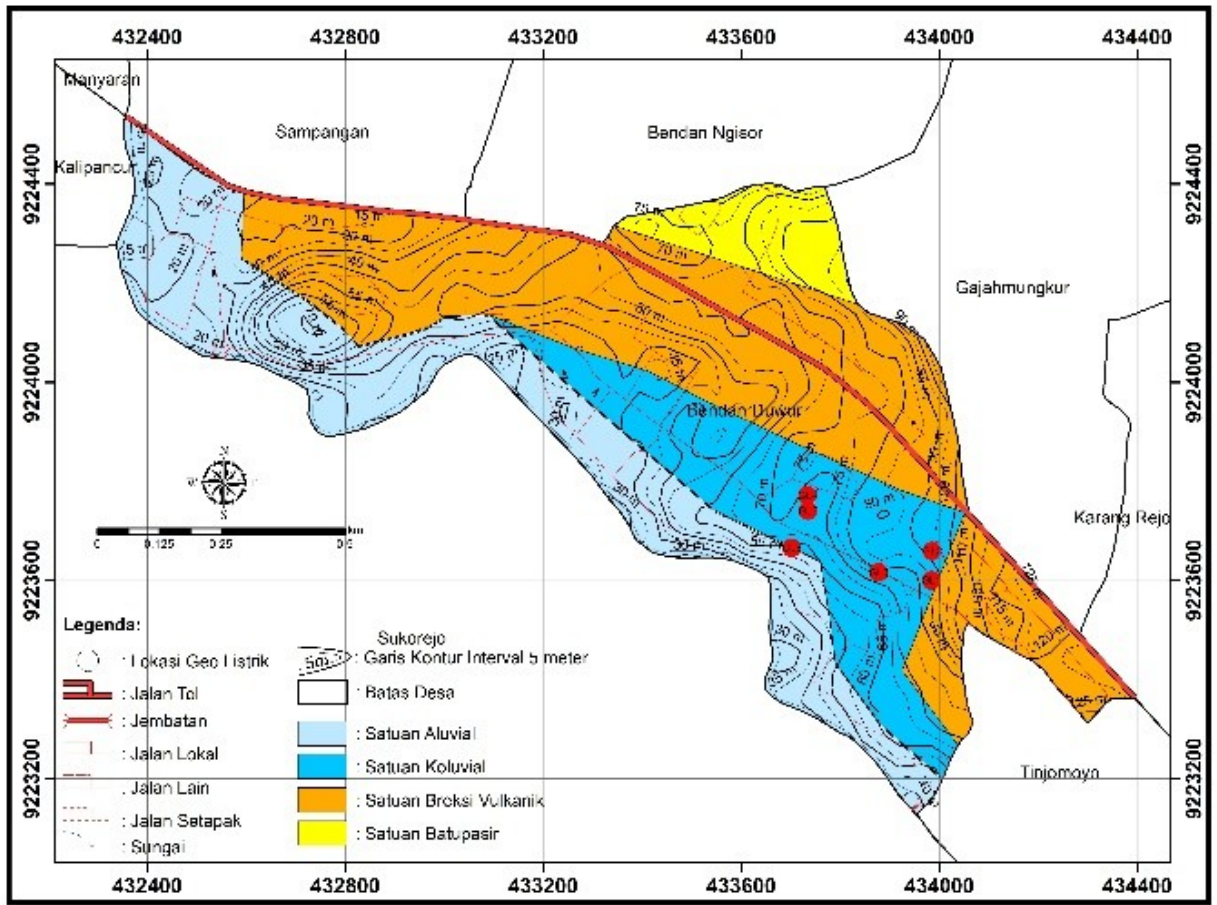

Fig. 3.Lithology Distribution Map in Research Area 

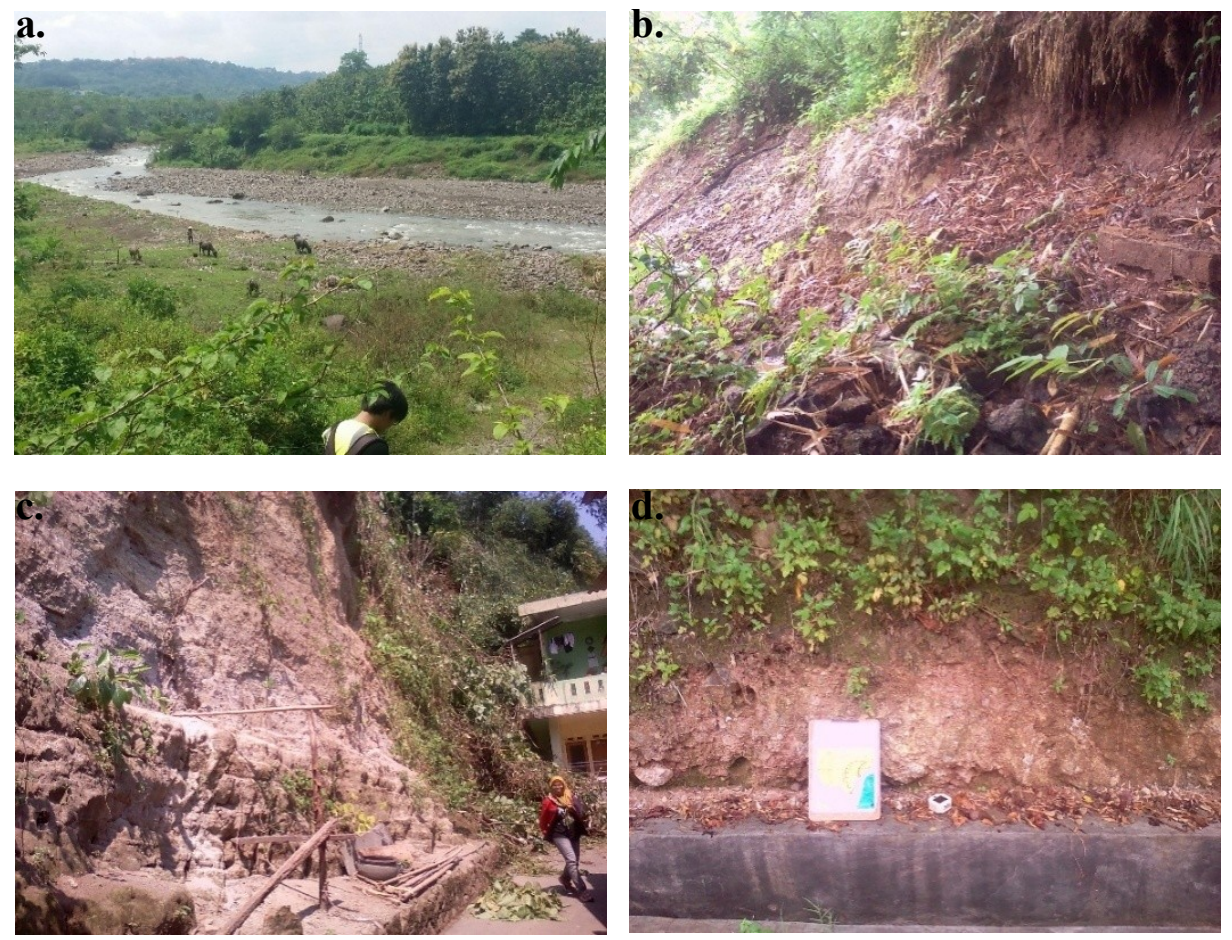

Fig. 4.Lithology in research area a. Alluvial Deposit, b. Colluvial Deposit, c. Tuffaceous Sandstone, d. Volcanic Breccia.

\subsubsection{Resistivity}

Resistivity methods are performed at 6 point measurements (Fig.3). The result of the interpretation using matching curve on the false resistivity data obtained at the time of resistivity measurement and software analysis of Progress 3.0, known that in the research area found lithology variation from surfaceare:

a. Colluvial deposits with resistivity value from 7,12 $\Omega \mathrm{m}$ to $27,1 \Omega \mathrm{m}$, with a thickness ranging from 0 to 2 $\mathrm{m}$.

b. Clay layer below colluvial deposits with resistivity value range from $0.18 \Omega \mathrm{m}$ to $10.58 \Omega \mathrm{m}$.

c. Tuff with resistivity value range $11,72 \Omega \mathrm{m}-36,08$ $\Omega \mathrm{m}$, found at depth above $3 \mathrm{~m}$.

d. Tuffaceoes sand with resistivity range 57,24 - 77,5 $\Omega \mathrm{m}$.

\subsection{Analysis of Distribution of Material Landslide}

Based on the results of the interpretation from image shows changes occur almost all areas of research. From overlay Landsat $7 \mathrm{ETM}+$ and DEM shows clearly that the changes on the eastern side of the study area with the dominant land use of shrubs are caused by the movement of the soil. This is indicated by a change which parallel to the lineament, where the lineament has a pattern parallel to the river. Changes that occur this can be an indication of changes in landform . In contrast to the south side of the study area, the changes that occur massive (almost in all locations) with relatively equal elevation. The change is in residential land use, so it can be indicated that changes occur in the land cover.

Based on the results of lithology mapping and resistivity measurements shows the correlation of the type of landslide that occurred at the study area. Landslide type is creep and material type of spread flow. Tuffaceous sandstone that lies above the volcanic breccia are more susceptible to weathering due to exposure on the surface. The tuff properties that absorb water accelerate the weathering process, resulting in the tuff being converted into clay. The correlations of resisitvity measurements at points 4.5 and 6 (Fig.7) show that the clay layer is above the tuff indicate that the clay is the result of tuff weathering.

\section{Conclusion}

Based on the results of research concluded that, landslide that occurred in the research area is creep then crown of landslide is in the southeast of the research area. A landslide leading to south, leads to the Kaligarang river, proving that the pawiyatan road is above the landslide material. Colluvial material is the result of rupting tuffaceous sandstone above the volcanic breccia. 


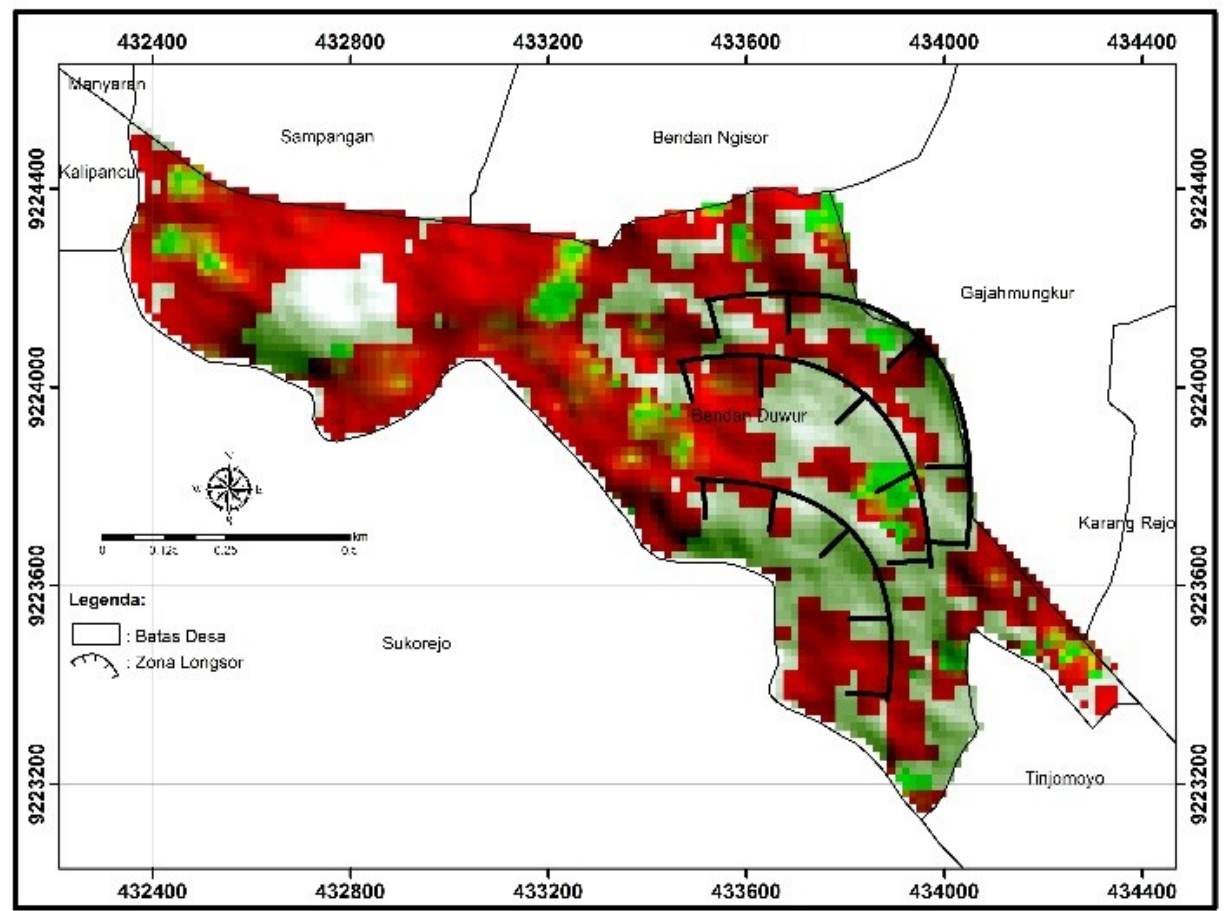

Fig. 6. Overlay of landsat image processing and DEM

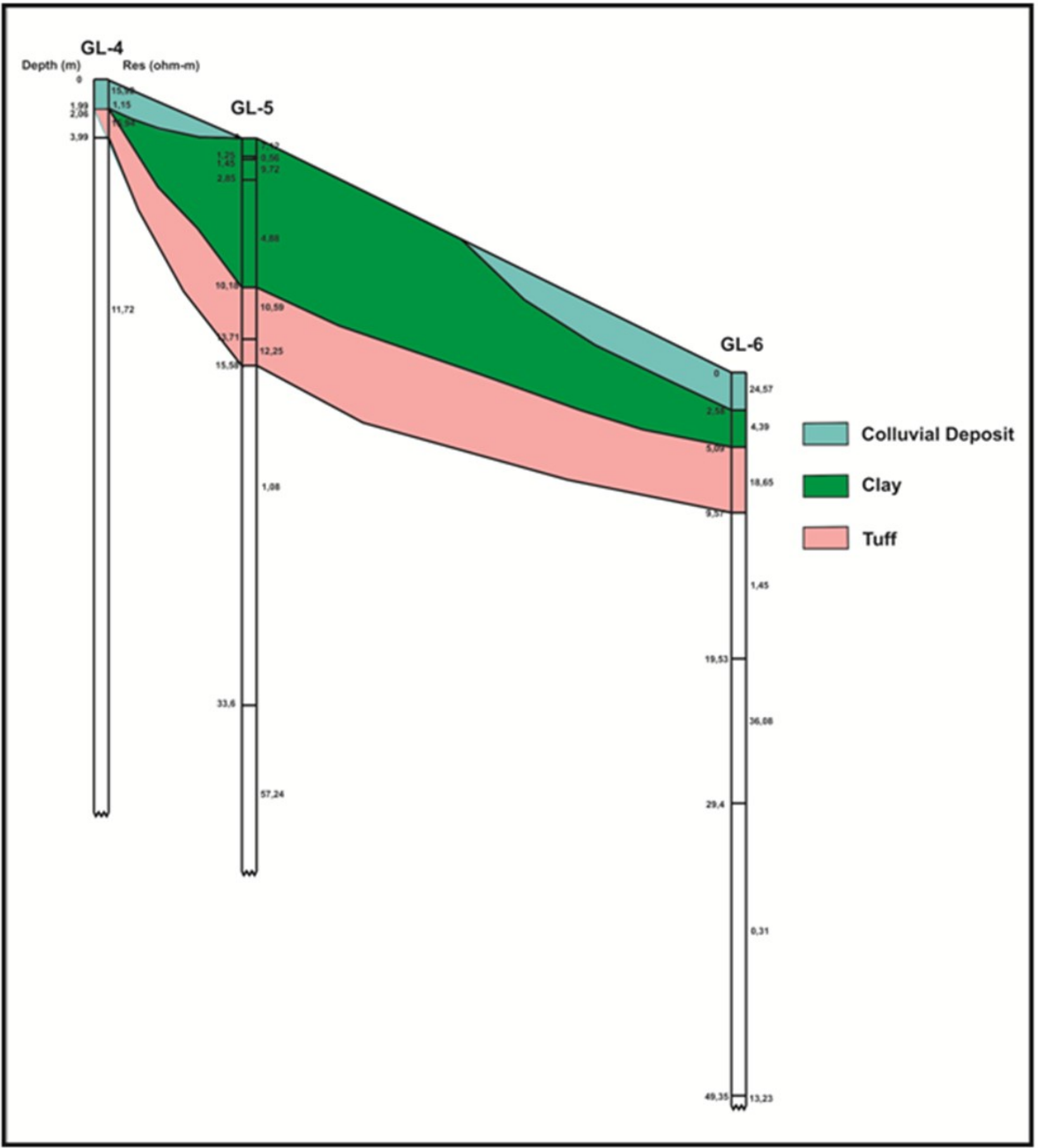

Fig. 7. Correlation resistivity log between GL-4, GL-5 and GL-6. 


\section{Acknoledgment}

The author thanks to Geological Department of Diponegoro University that supply support to do research and research funding. The thanks also go to parties who have been willing to provide corrections, criticisms, suggestions and input, so that the research and writing of this paper can be resolved.

\section{References}

1. D. Karnawati. Bencana Alam Gerakan Massa Tanah di Indonesia dan Upaya Penanggulangannya (2005)

2. R. Soeters, and C.J. van Western. Landslides: Investigation and Mitigation, Transportation Research Board, National Research Council, Special Report 247, 129-177 (1996)

a. Ciampalini, F. Raspini, S. Bianchini, W. Frodella, F. Bardi, D. Lagomarsino, F. Di Traglia, S.Moretti, C. Proietti, P. Pagliara, R. Onori, A.Corazza, A. Duro, G. Basile, N.Casagli.J. Geomorphology 249, 103-118 (2014)
3. N. Casagli, F. Cigna, S. Bianchini, D. Hölbling, P. Füreder, G. Righini, S. DelConte, B. Friedl, S. Schneiderbauer, C. Iasio, J. Vlcko, V. Greif, H. Proske, K. Granica S. Falco, S. Lozzi, O. Mora, A. Arnaud, F. Novali, M. Bianchi. J.RSASE 4, 92-108 (2016)

4. C. H. Hsu, T. C. Tsao, C. M. Huang, C. F. Lee, Y. T. Lee.Procedia Engineering 143, 708-716 (2016).

5. P. Rachwibowo. Proceedings PIT IAGI Ke 39 (2010)

6. D.M. Cruden and D. J. Varnes. Landslides: Investigation and Mitigation, Transportation Research Board, National Research Council, Special Report 247, 36-75(1996)

7. W. M. Telford, L. P. Geldart and R. E. Sheriff. Applied Geophysics (1990)

8. T. T. Putranto, N. Susanto, D. J. Suprapto, N. Anatoly, A. Rifqi. Proceeding Seminar Kebumian $\mathrm{Ke}-8,87-97$ (2015)

9. R. E. Thanden, H. Sumadirdja, P. W. Richards, K. Sutisna and T.C. Aim. Peta Geologi Lembar Magelang dan Semarang, Jawa Skala 1:100.000 (1996) 